\title{
A MATHEMATICAL TOOL KIT FOR GENERATIVE JUSTICE'
}

\author{
UM CONJUNTO DE FERRAMENTAS MATEMÁTICAS \\ PARA A JUSTIÇA GENERATIVA
}

\author{
UN CONJUNTO DE HERRAMIENTAS MATEMÁTICAS \\ PARA LA JUSTICIA GENERATIVA
}

Ron Eglash ${ }^{1}$, Audrey Bennett ${ }^{2}$, John Drazan ${ }^{3}$, Michael Lachney ${ }^{4}$, William Babbitt ${ }^{5}$

\begin{abstract}
How can mathematics best contribute to social justice and sustainability? Distributive justice addresses poverty and related problems from the top down: by moving extracted value from private to state ownership. But, the history of bureaucratic socialism, from the pollution in the USSR to food shortages in Venezuela, shows just as many problems as capitalism. Generative justice, in contrast, works from the bottom up: replacing value extraction and alienation with value circulation. These generative cycles include unalienated labor, such as that we find in makerspaces and open source; unalienated ecological value such as organic farming, and unalienated expressive value such as sexual diversity, liberated arts, and other polysemic freedoms. This essay will review 3 aspects of ethnosciences (ethnomathematics, ethnocomputing and related disciplines) in relation to generative justice. In the case of indigenous knowledge systems, there is a danger of alienation of value as concepts are translated into models, and further abstracted into classroom curricula. In the case of vernacular knowledge systems, colonization by commercial interests has already occurred, and the challenge is to develop a decolonized alternative. Finally, in the case of school-community relations, a full generative cycle can incorporate economic, health and environmental flows of value by leveraging these generative STEM approaches. This essay will provide both theory and some initial results of this generative STEM approach to a more just and sustainable world.
\end{abstract}

KEYWORDS: Ethnocomputing. Generative Justice. Self-organization. Nonlinear Dynamics. Indigenous. Ethnomathematics.

\section{RESUMO}

Como a matemática pode melhor contribuir para a justiça social e a sustentabilidade? A justiça distributiva aborda a pobreza e os problemas relacionados de cima para baixo: movendo o valor extraído da propriedade privada para a propriedade estatal. Mas, a história do socialismo burocrático, da poluição na URSS à escassez

\footnotetext{
${ }^{1}$ Professor Department of Science and Technology Studies - Rensselaer Polytechnic Institute (RPI) - Troy, NY, Estados Unidos da América do Norte. E-mail: eglash@rpi.edu

${ }^{2}$ Professor - Rensselaer Polytechnic Institute (RPI) - Troy, NY, Estados Unidos da América do Norte. E-mail: bennett@rpi.edu

${ }^{3}$ Graduate Teaching Assistant - Rensselaer Polytechnic Institute (RPI) - Troy, NY, Estados Unidos da América do Norte. E-mail: drazaj@rpi.edu

${ }^{4}$ Professor - Rensselaer Polytechnic Institute (RPI) - Troy, NY, Estados Unidos da América do Norte. E-mail: lachnm@rpi.edu

${ }^{5}$ Professor - Rensselaer Polytechnic Institute (RPI) - Troy, NY, Estados Unidos da América do Norte. E-mail: bbabbitt2003@gmail.com
}

Submitted in: 25/02/2017 Accept: 31/05/2017

(C) ETD-Educação Temática Digital Campinas, SP v.19 n.3 p. 761-785 jul./set. 2017


de alimentos na Venezuela, mostra tantos problemas quanto o capitalismo. A justiça generativa, ao contrário, funciona de baixo para cima: substitui a extração de valor e a alienação pela circulação de valores. Esses ciclos geradores incluem os trabalhos não alienados, como, por exemplo, os espaços de produção e os códigos abertos; valores ecológicos não alienados como a agricultura orgânica e valores expressivos não alienados como a diversidade sexual, as artes liberadas e outras liberdades polissêmicas. Este ensaio revisará 3 aspectos das etnociências (etnomatemática, etnocomputação e disciplinas relacionadas) em relação à justiça generativa. No caso dos sistemas de conhecimento indígena, há um perigo de alienação do valor à medida que os conceitos são traduzidos em modelos e, posteriormente, abstraídos em currículos de sala de aula. No caso dos sistemas de conhecimentos vernaculares, a colonização por interesses comerciais já ocorreu, e o desafio é desenvolver uma alternativa descolonizada. Finalmente, no caso das relações entre a escola e a comunidade, um ciclo generativo completo pode incorporar fluxos de valores econômico, de saúde e ambientais, alavancando essas abordagens generativas CTEM (Ciências, Tecnologias, Engenharia e Matemáticas). Este ensaio fornecerá, ambos, a teoria e alguns resultados iniciais dessa abordagem generativa CTEM para um mundo mais justo e sustentável.

PALAVRAS-CHAVE: Etnocomputação. Justiça Generativa. Auto-Organização. Dinâmicas Não-Lineares. Indígena. Etnomatemática.

\section{RESUMEN}

¿Cómo pueden las matemáticas contribuir mejor a la justicia social y la sostenibilidad? La justicia distributiva aborda la pobreza y los problemas relacionados desde arriba hacia abajo: moviendo el valor extraído de propiedad privada a propiedad estatal. Pero la historia del socialismo burocrático, desde la polución en la URSS hasta la escasez de alimentos en Venezuela, muestra tantos problemas como el capitalismo. La justicia generativa, por el contrario, trabaja de abajo hacia arriba: reemplazando la extracción de valores y la alienación por la circulación de valores. Estos ciclos generativos incluyen una labor inalienable, tal y como se encuentra en los espacios de los fabricantes y las fuentes abiertas; el valor ecológico inalienable como la agricultura orgánica y el inalienable valor expresivo de la diversidad sexual, las artes liberadas y otras libertades polisémicas. Este ensayo revisará 3 aspectos de las etno-ciencias (etnomatemáticas, etnocomputación y disciplinas relacionadas) en relación con la justicia generativa. En el caso de los sistemas de conocimiento vernáculos, existe un peligro de alienación del valor, a medida que los conceptos son traducidos en modelos y son más abstraídos en los programas de estudio de las aulas. En el caso de los sistemas de conocimiento vernáculos, la colonización por intereses comerciales ya ha ocurrido, y el desafío es desarrollar una alternativa descolonizada. Por último, en el caso de las relaciones entre la escuela y la comunidad, un ciclo generativo completo puede incorporar flujos con valores económicos, sanitarios y ambientales, aprovechando estos enfoques generativos de CTIM (Ciencia, Tecnología, Ingeniería y Matemática). Este ensayo proporcionará tanto teoría como algunos resultados iniciales de este enfoque CTIM generativo hacia un mundo más justo y sostenible.

PALABRAS CLAVE: Etno-computación. Justicia Generativa. Auto-Organización. Dinámica no Lineal. Indígena, Etnomatemática.

\section{INTRODUCTION}

How can mathematics and computing best contribute to social justice and sustainability? STEM (Science Technology, Engineering, and Mathematics) practices at the hands of corporate capitalism have resulted in global warming, toxic environments, massive wealth inequality, deskilling of labor, and other deleterious outcomes. At the same time, a history of socialist disasters-pollution in the USSR, Maoist child soldiers in Nepal, human rights violations in Cuba, food shortages in Venezuela, and so on-show that centralized

(C) ETD-Educação Temática Digital $\quad$ Campinas, SP $\quad$ v.19 $\quad$ n.3 $\quad$ p.761-785 jul./set. 2017


government control can also suffer from similar problems. Prior work ${ }^{6}$ by our team (EGLASH; GARVEY, 2014; EGLASH 2016a; LYLES, LACHNEY, FOSTER; ZATZ, 2016) has introduced the concept of generative justice as an alternative framework.

Generative systems are organized from the bottom up rather than the top down, and focus on circulating value in unalienated form rather than extracting value for use by corporations or governments. We can see generative justice at work in the circulation of code through open source communities; the circulation of nutrients in agroecology; and the circulation of expressive value in free speech, sexual liberation, spiritual freedom and other counter-hegemonic cultural practices. The explosion of a global DIY economy ranging from makerspaces to urban agriculture, powered by open and shared technologies such as 3D printing and Arduino microprocessors is just one of the more visible aspects of this emergence.

This essay will briefly explain the concept of generative justice in the first section, summarizing prior work. I refer the reader to Eglash (2016a, 2016b) for more details. We will then review the role of ethnomathematics, ethnocomputing and similar "translations" of indigenous knowledge to STEM, and examine how those relationships can be improved with a generative perspective and techniques.

\section{GENERATIVE JUSTICE}

Generative systems are by definition "self-generating". Consider, for example, how a seed grows into a tree; a species evolves an adaptation; an idea blossoms into a social movement. These are all phenomena in the category of self-organizing systems, the primary object of study to mathematicians and scientists in the contemporary field of complexity theory ${ }^{7}$. But, humanists, artists, indigenous knowledge practitioners and others have long known that there is something special about the ways people and nonhuman organisms can recursively generate their own value.

Karl Marx began his analysis of communism with the idea that indigenous societies allowed people and environments to retain value in unalienated form, sharing goods and services through a "commons". These observations have been upheld by modern anthropologists, who confirm that many hunter-gatherer and horticultural societies had relatively egalitarian societies with little wealth inequality and (at least for some) little

\footnotetext{
${ }^{6}$ For a broader collection of articles see the special issue on generative justice at http://revistas.ucm.es/index.php/TEKN/issue/view/2944/showToc.

${ }^{7}$ See Mitchel (2009) for an introduction.

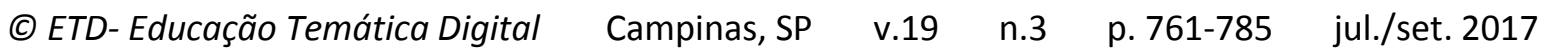


gender inequality. For example, the Iroquois (the main focus of Marx's ethnographic analysis) established women's right to vote centuries before European or American nations did so; established communal labor crews so that all families received sufficient help with farming, and a food commons for sharing the fruits of their labor.

Figure 1 is a flowchart from Eglash (2016b) showing the cycles of unalienated value in traditional Iroquois society. Note that it begins with a nonhuman generative cycle within the human cycles as the three sisters (corn, beans and squash) create an agroecology exchange (beans fix nitrogen into the soil for corn and squash; corn provides support for bean vines; squash decreases water loss, pests and weeds with broad spiny leaves). Double lines like pipes are used to indicate unalienated value.

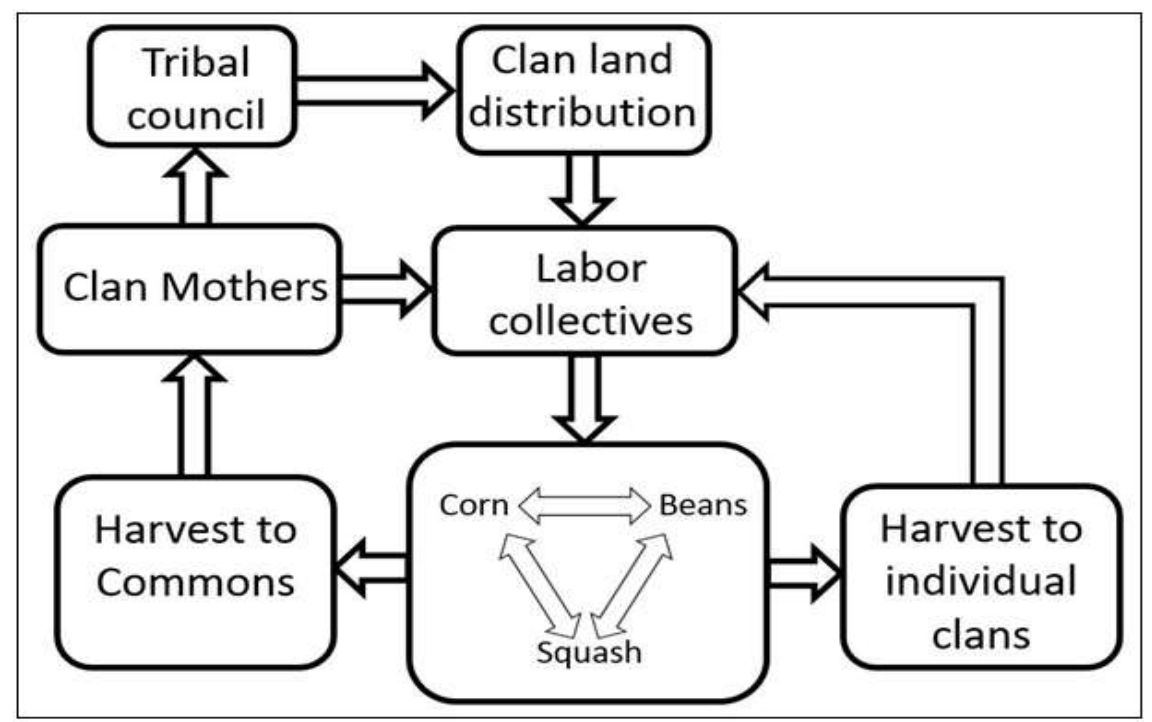

FIGURE 1 - Flow chart for unalienated value flow in a traditional Iroquois economy Source: The authors

From Marx's view, capitalism forces the value that labor produces to become "alienated" from the workers who produced it. In contrast to indigenous circulation, capitalism "extracts" value from its generative system. Although Marx primarily focused on labor value, he did make some comments about the same process by which ecological value is alienated from its generative source. In the 1860 s he critiqued capitalist agriculture for the way it:

(...) disturbs the metabolic interaction between man and the earth, i.e. it prevents the return to the soil of its constituent elements consumed by man in the form of food and clothing (...). All progress in capitalist agriculture is a progress in the art, not only of robbing the worker, but of robbing the soil (MARX, 1976, p. 637-638).

$\begin{array}{llllll}\text { (c) ETD-Educação Temática Digital } & \text { Campinas, SP } & \text { v.19 } & \text { n.3 } & \text { p.761-785 } & \text { jul./set. } 2017\end{array}$ 
Figure 2 shows how this extraction process looks when envisioned by a flow chart. Labor and nature generate value, but most of it is extracted by the owners of factories, forest industries, and so on (for that reason the value flow is drawn as single lines). We did not bother to show what little does get returned, but note that is also in alienated form: wages to be spent on commodities that only increase the desire for more commodities; artificial soil supplements that cannot sustain the natural soil microfauna, and pesticide "treadmills" specialized for monocropping and destructive of the biodiversity that indigenous techniques would have supported.

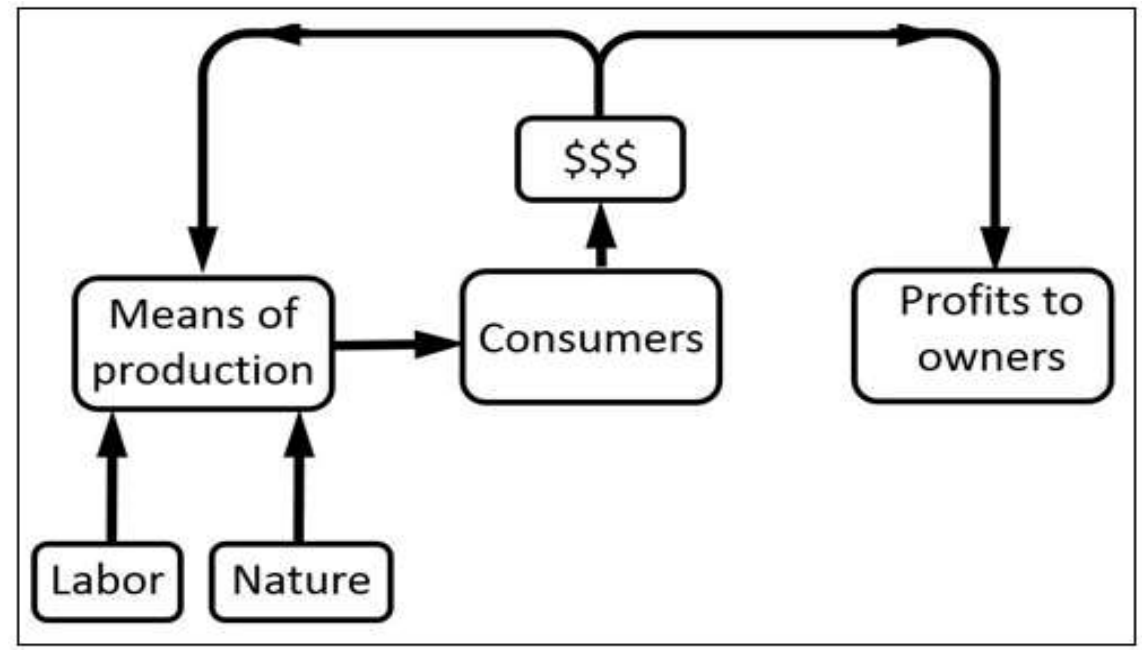

FIGURE 2 - Flow of alienated value under capitalism

Source: The authors

Tragically, bureaucratic socialism has shown little difference with capitalism: replace "profits to owners" with "profits to the state" and figure 2 could easily describe centralized communism. In China today the largest 12 companies are owned by the government, but the "people's pollution created" by these corporations is just as toxic as that of capitalism's pollution. Burawoy (1985), a sociologist who spent years in participant ethnography as a shop floor worker in both capitalist and communist metal industries, found that life "in the people's factory" was just as oppressive as that of capital's. Marxists might protest, "but that is not communism as Marx envisioned it" - true, but the disasters created by capitalism are not as Adam Smith envisioned it either. As scholars and scientists, we need to allow even our most cherished hypotheses to be falsified when the data contradicts it. But, where did Marx go wrong?

Marx maintained that indigenous societies, admirable though their unalienated relations might be, would always be enslaved to "nature's paltriness" (Natur-bedurftigkeit): teedering on the edge of starvation, prone to droughts or floods, ravaged by disease. He claimed that the efficiencies required to free ourselves from this animal-like existence could only be achieved by extracting value, just as capitalism does, and then centralizing it
(C) ETD-Educação Temática Digital
Campinas, SP
v.19 n.3
p. 761-785
jul./set. 2017 
through state ownership, where redistribution could enforce egalitarian relations (EGLASH, 2016a). Marx was wrong on two counts.

First, once value is in an alienated form, it is almost impossible to set things right again. Extracting ecological value from soil by agriculture, but returning that value in the alienated form of chemical amendments and pesticides causes soil depletion. Extracting labor value by putting workers into meaningless jobs, and returning value in its alienated form of minimum wage creates meaningless consumption, as workers try to regain selfworth through shopping malls and commodified entertainments.

Second, the model of unalienated value circulation offered by indigenous societies is not trapped in a low-tech past. Indeed we are in an era in which generative alternatives circulating value in unalienated form, rather than extracting - are increasingly enabled by technological innovation. Open source software, the makerspace movement, urban gardens, DIY energy systems, commons-based peer production and many other structures and practices allow users to share and exchange value in unalienated form, as it did in indigenous societies, but leveraged by contemporary technologies. In addition to labor value and ecological value, we must add the category of expressive value. In commons-based peer production, for example, users engage in a variety of collaborative sharing practices ranging from radical LGBTQ activist organizing to whimsical fan fiction and cat videos.

Figure 3 shows a flowchart for an example of open source hardware, the Arduino microprocessor. Note that I have used single lines to show the flow of extracted value, and double lines to show unalienated value. Elsewhere (EGLASH, 2016b) I have detailed how its networks of production include 3 processes: at lower right, we see the generative justice of commons-based peer production, in which an online community shares open source designs, code and circuits through Creative Commons, GitHub or other non-proprietary means (BENKLER, 2006; EGLASH; BANKS, 2014). 


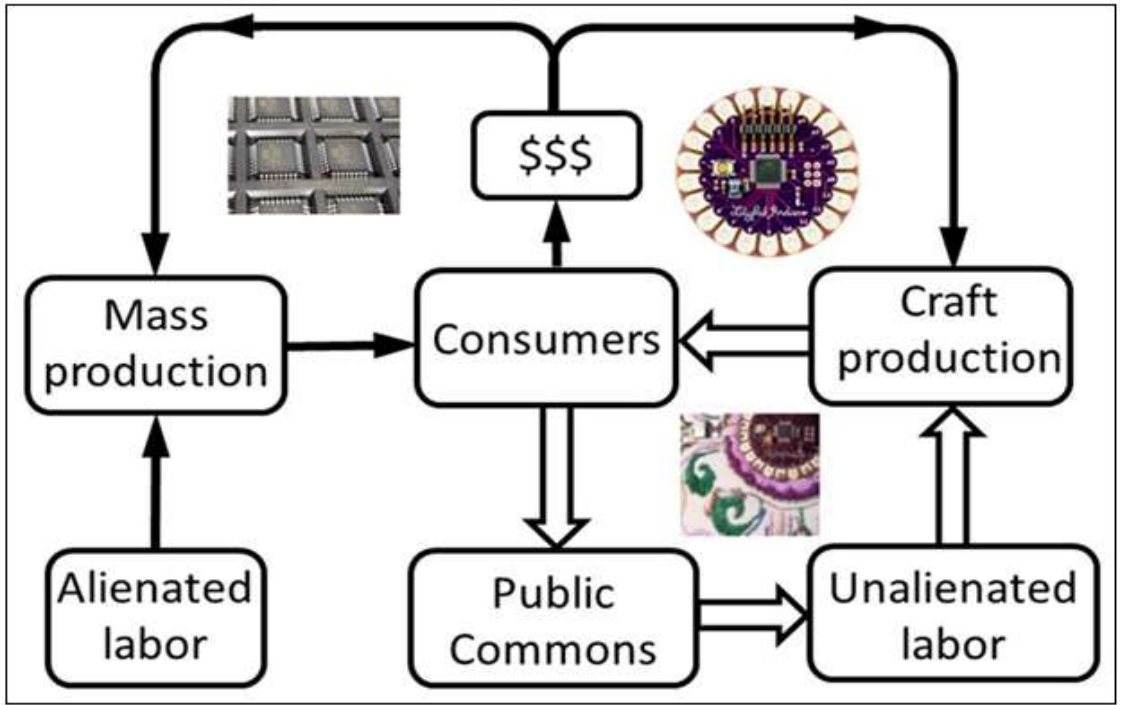

FIGURE 3 - Generative justice cycle at lower right, extractive production at left, hybrid cycle at upper right

Source: The authors

At upper left, regrettably, exploitative mass production continues to supply some of the components. But, at upper right, we see a hybrid cycle which is both open source and for-profit. In this case it is the LillyPad, a version of the Arduino that was designed by MIT researcher Leah Buechly to inspire more participation by girls by making an easier integration with electronic textiles for "maker" activities. Buechly and Hill (2010) showed a statistically significant rise in the number of female names purchasing these units. And because it is open source, she could start her own company, making the social justice change self-sustaining.

Arduino projects have inspired an enormous range of similar small scale start-ups, many having social justice or sustainability dimensions due to the influence of an enormous online community of DIY or "maker" enthusiasts (EGLASH, 2016b). As more of these startups begin to take over the functions that were previously carried out by the exploitative production of the upper left in figure 3 , there is the possibility of a global shift towards generative justice. That is by no means "automatic"; it can only happen through deliberate efforts such as pressure from social movements that support generative solutions (DUNBARHESTER, 2016).

\section{Orthogonality of the Generative Axis to the Socialist-Capitalist Axis}

The first of our mathematical tools is the humble Cartesian grid. We are used to thinking of social issues as a single axis of capitalist versus socialist, or right versus left. A generative perspective requires us to think about this domain as having two orthogonal
(C) ETD-Educação Temática Digital
Campinas, SP
v.19 n.3
p. $761-785$
jul./set. 2017 
axes. Scientists have long known that phenomena which act independently can be mapped on such a grid. For example, certain diseases such as cholera appeared to be caused by "miasma" or "bad air". Under this (incorrect) theory one need only map the single axis of good air versus bad air to predict the incidence of cholera. It was only after finding a cholera outbreak in a "good air" area - documenting the fact that these are independent phenomena - that the two could be seen as orthogonal dimensions (PANETH, 1998).

Similarly, the full range of extractive versus generative phenomena occur independently of the socialist-capitalist axis, forming an orthogonal dimension. A good example of the extractive extreme in labor is the practice of Taylorism: decomposing labor activity into deskilled movements, and timing them to make sure they are paid the minimum amount possible. Taylorism peaked in the US around 1910, but it was enthusiastically embraced by the USSR until the 1930s (BESSINGER, 1988). A good example of the generative extreme in labor would be worker-owned cooperatives. Here labor - not capital owners or state bureaucrats - determines how work is carried out, what products are made, and how pay is determined.

In 1968, for example, Czechoslovakia briefly experienced the "Prague Spring" in which workers took control of factories. Because directly circulating unalienated value putting workers in charge of their own work - was in direct violation of the Marxist principles of centralization, the USSR invaded Czechoslovakia and ended their generative experiment (VITAK, 1971). Similar barriers to worker-owned production has occurred under capitalism: not facing an invasion of soviet tanks, but merely worn down by competition from large corporations (GEO, 2012).

Conversely, worker-owned cooperatives have occasionally flourished under both socialism and capitalism. Thus the generative-extractive axis meets the criteria for orthogonality (figure 4). Worker cooperatives do not always succeed in preventing value extraction, at least not $100 \%$, but many examples such as Alvarado Bakery in California or Namasté Solar in Colorado combine democratic sharing of labor and profits with ecological sustainability, healthier diets and other benefits. 


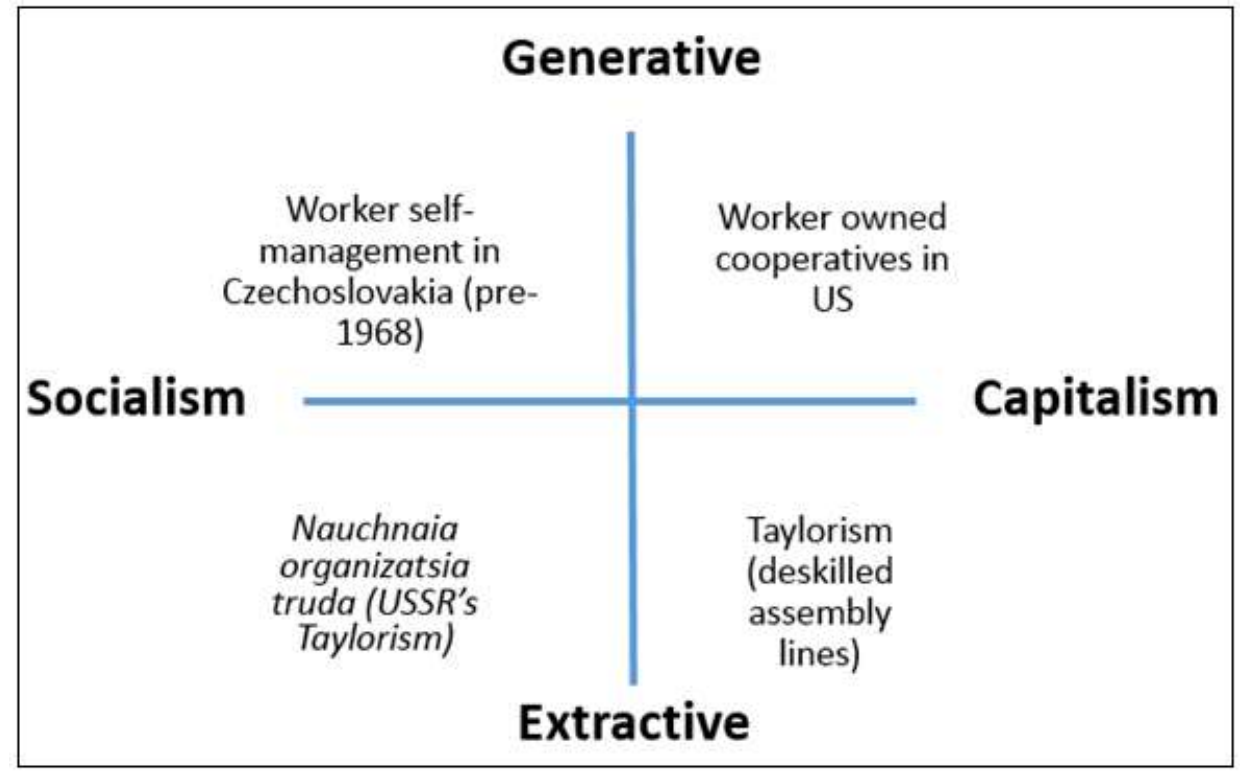

FIGURE 4 - The generative justice axis is orthogonal to the socialist-capitalism axis

Source: The authors

In sum: it is just as much a challenge to create the "direct democracy" of workerowned factories under socialism as it is under capitalism; just as difficult to achieve free expression for LGBTQ identities; healthy organic foods for all, and so on. Thus, we arrive at the following definition for generative justice: The universal right to generate unalienated value and directly participate in its benefits; the rights of value generators to create their own conditions of production; and the rights of communities of value generation to nurture self-sustaining paths for its circulation.

\section{GENERATIVE JUSTICE AND ETHNOSCIENCES: THE CHALLENGE OF KEEPING VALUE IN UNALIENATED FORM}

Ethnomathematics, ethnocomputing and similar practices - lets call them ethnosciences constitute the second instrument in our mathematical toolbox. Such "ethnomodeling" (ROSA; OREY, 2013) translates between the local artifacts or practices and their counterparts or "analogues" (EGLASH, 2009) in western mathematics, computing or other western STEM. There is a clear relationship, at least in the ideal case, to the goals of generative justice. When traditional societies were creating algorithms in hand-loomed weaving patterns, or carving nonlinear curves into their indigenous artifacts, they were doing so through the unalienated labor originally envisioned by Marx. Cycling that value back to children in that community, such that their education can nurture those unalienated lifeways, necessitates a generative cycle, or as we have termed it elsewhere, "generative STEM" (COOKE, 2016).

(C) ETD- Educação Temática Digital $\quad$ Campinas, SP $\quad$ v.19 $\quad$ n.3 $\quad$ p.761-785 $\quad$ jul./set. 2017 
The value flow in the case of generative ethnosciences would be just like open source software developers freely releasing code into a digital commons, where it can go back to other developers; become further modified, and so on. Another similar case would be organic gardening cycles in which organic waste is composted into soil nutrients, and back to plants, to be eaten and turned into more compostable waste. In the open source case it is labor value; in the gardening case it is ecological value; and in the ethnosciences case it is expressive value. But, there are at least 3 complications we must grapple with to make the ethnosciences consistent with generative justice. In this section we will consider the problem of value alienation in the process of moving from indigenous knowledge to the classroom.

How can we ensure that ethnomathematics and similar translations are not simply extracting value and using it for purposes that do not benefit the societies which generated it? After all, the pharmaceutical industry has notoriously used "bioprospecting"indigenous medical knowledge of plants - and often committed "biopiracy," reaping millions in profits with little or no return to the society that discovered it (CLUIS, 2013).

In our own work on ethnocomputing (BENNETT, 2016; LACHNEY et al., 2016a) we begin by asking indigenous representatives - elders, artisans, indigenous scholars, etc. - if the way we are proposing to use the material is permissible, making it clear that these will be educational computing simulations available for free globally. Occasionally the answer is no - for instance, a Shoshone elder once told us that a physics simulation of their traditional spinning disk would not be permissible, because of its use in sacred ceremonies. In another instance, Navajo artisans told us that a photo of a sand painting could not be used, but, a photo of a rug based on a sand painting would be permissible because crucial details had been omitted. But on the whole, indigenous representatives have been strikingly enthusiastic about translating their knowledge systems into STEM for our particular set of projects.

They typically tell us that is in part because we promise not to charge for access once we make it clear that we are following their directives about which artifacts and practices are permissible, and make a convincing case that it will be portrayed in a respectful way, they make clear a desire to see their traditional knowledge be of benefit to everyone. But, "respectful" means avoiding the decontextualizing that the process can inadvertently tend towards: all of our tools (www.csdt.rpi.edu) begin with a cultural background section that details who the group is, how the artifact is used or created, and its

(C) ETD-Educação Temática Digital $\quad$ Campinas, SP $\quad$ v.19 $\quad$ n.3 $\quad$ p.761-785 jul./set. 2017


meaning and significance. Here we describe that for the case of our wigwam simulation (http://csdt.rpi.edu/na/arcs).

This project began with the use of our virtual beadloom by Rich Sgarlotti, a Potawatomi Nation school teacher and adjunct mathematics professor at Northern Michigan University. Rich noted the importance of wigwaam structures to their traditional culture, and asked if we could create the tool (figure 5).

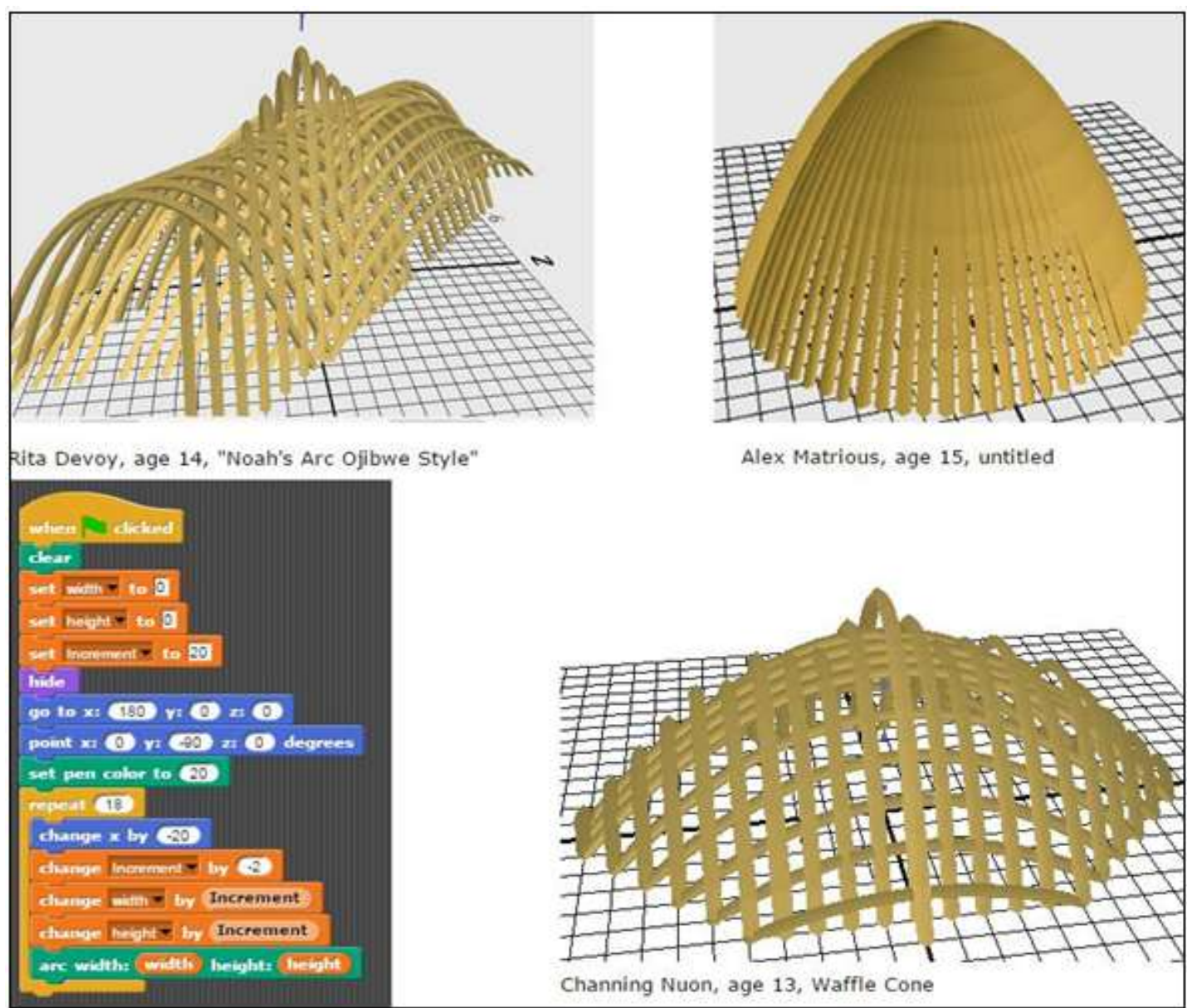

FIGURE 5 - The programming interface and samples of student work from the anishinaabe arcs tool Source: The authors

On our first visit we happened to run into their language instructor, Kenn Pitawanakwat, and together we came up with a plan to record his voice so that students could use a "mouse-over" to hear the translation of key terms. In discussing how far wood can bend before breaking, we had used the physics concept of "modulus of rupture". Kenn created a new word on the spot, epiichiiyimigak (from the phrase "how much weight can it take"). The neologism inspired us to look deeper into how the Potawatomi determined which saplings had the optimal combination of flexibility and resistance.
(C) ETD- Educação Temática Digital
Campinas, SP
v.19 n.3
p. $761-785$
jul./set. 2017 
Their team had a video recording of elder Earl Otchingwanigan as he selected materials in the woods for a wigwam, discussing the effects of dry versus wet environments on sapling development, and Kenn noted how their concept of tree "personhood" (naagidewenjigon) required ecological care (for example limiting root harvests to prevent tree damage). These too became incorporated into the website, improving its recognition for their expressive value of spirituality, the ecological value of sustainable harvests, and the pedagogical utility to a broader STEM curriculum. It also changed our pedagogical style, because we began to incorporate an exercise in which children bend fresh willow branches to feel it springing back in their hands. This broader view encourages children to be more creative in their use of the tool; as can be seen in figure 5 they modified traditional wigwam structures into their own re-imaginings.

Typically ethnomathematics takes a one-way path: from indigenous knowledge to "translation" into Western mathematics and finally reinterpretation into a classroom lesson. The typical claim to any kind of STEM diversity effort lies in the assumption that this will improve learning outcomes, and thus benefit the children of the underserved community. As we will see shortly, this is not always a reliable assumption. However the epiichiiyimigak example shows that we do not have to lean on that crutch as our only justification.

Here we see how a generative cycle can be embedded in a design process that resists the tendency for software and educational contexts to be abstracting and alienating to the cultural material, and (hopefully) lends itself to nurturing a value flow under control of those who generated it. Changing the original design to incorporate native language retention efforts further influenced our methods, which further adapts the design to recognize their cultural relations to nature. That is, we shift from a one-way ethnomodeling to a recursive process (LACHNEY et al., 2016a), which better facilitates the flow of unalienated value between community and school (LACHNEY, 2016).

More broadly, since our website offers tools based on many cultures, the Potawatomi students in our workshop had the opportunity to examine Navajo weavings, Shoshone beadwork and other simulations. Similarly we have seen African American and Latino/a children experiment with Native American simulations, and in some cases they borrow and develop hybrids that blend cultural elements. In one case we had an African American student using a Native American beadloom to create a Jamaican flag; and later a Navajo student who copied the flag color scheme from the simulation and incorporated it into her virtual rug design. Elements from popular culture are sometimes integrated as well; usually in a humorous or ironic spirit (see titles in the student samples in figure 5). In our
(C) ETD-Educação Temática Digital
Campinas, SP
v.19
n.3
p. $761-785$
jul./set. 2017 
community site (www.community.csdt.rpi.edu) students can download a cultural simulation, modify it, and upload their own version in a true open source fashion.

In summary: a generative STEM approach in which we attempt to keep value in unalienated form begins with permission-based, respectful use. It also requires a participatory design process; ideally one in which thoughtful reflection can inspire a recursive knowledge exchange rather than placing one group as the epistemological "raw materials" mined for mathematics extraction. And it helps to allow non-proprietary sharing, modeled on the indigenous commons. However that is only one part of the full requirements for generative STEM.

\section{GENERATIVE JUSTICE AND ETHNOSCIENCES II: THE CASE OF VERNACULAR KNOWLEDGE}

Above we covered the danger that value might be alienated when moving from indigenous knowledge to the classroom. Here we will discuss ethnosciences based on vernacular knowledge - skateboard physics, graffiti graphing, etc. - which have a different set of challenges. One system famous for its appeal in allowing children to simulate elements of their own local context is MIT's Scratch.

Lachney et al., (2016b) examine the claims of Scratch software to allow children to "become producers rather than consumers". They note that although Scratch has achieved the Papert's ideal of allowing children to develop their own topics for simulations, games and other applications, the subject matter is heavily influenced by marketing and commodities:

\footnotetext{
A search for Barbie on the Scratch community site leads to 2,960 results for animations, art, games, music, and stories all featuring the easily recognizable characters of Barbie and friends. Add to that 6,530 results for McDonalds; 4,600 for Disney Princess; 8,210 for Transformers; 17,400 results for Call of Duty; and numerous others such as Bratz, American Girl, Strawberry Shortcake, Power Rangers, Care Bears, My Little Pony, Adidas - let us not overlook over 3 million search hits for Pokemon - and one begins to see the problem with the Scratch website's motto, "We turn children from consumers into producers (p. 4).
}

Thus simply allowing children to choose subject matter for themselves, or to "draw from children's own culture or daily life" (a common ethnomathematics theme) is not sufficient to achieve a fully "democratized" version of STEM. Just as indigenous societies were colonized by imperial nations, childhood is often colonized by corporations; the "free choice" of their play an illusion masking the strong influence of marketing schemes. We are

(C) ETD-Educação Temática Digital $\quad$ Campinas, SP $\quad$ v.19 $\quad$ n.3 $\quad$ p.761-785 jul./set. 2017


accustomed to thinking of play as the opposite of labor, but both labor value and play value are similarly targets for exploitative extraction.

Decolonizing play for generative STEM means not only creating the usual ethnomathematics "translation" or ethnomodeling (ROSA; OREY, 2013) between the local artifacts or practices and western mathematics, but also helping to nurture authentic forms of play as exploration, self-growth, self-efficacy and self-reflection (a parallel to what Freire referred to as the use of a "generative theme" in open classroom dialogue). Bennett, Cassim, Van Der Merwe, Van Zijl, and Ribbens (2015) introduced the phrase "Generative Play" to describe the latter process. They created a studio classroom which included a psychologist specializing in play therapy, and had university design students in South Africa develop tangible tool kits that allow children creative agency as they explored various health and education topics.

Extending this work to ethnomathematics, Bennett (2016) used the term "ethnocomputational creativity" to describe her work with art classrooms. She began with Culturally Situated Design Tools (CSDTs), an online suite of computer simulations for ethnomathematics (www.csdt.rpi.edu). Working with high school art teachers, she had students move from their abstract designs in virtual space to rendering them as physical designs, using material ranging from ceramics to origami to glass jars with colored fluid (figure 6).

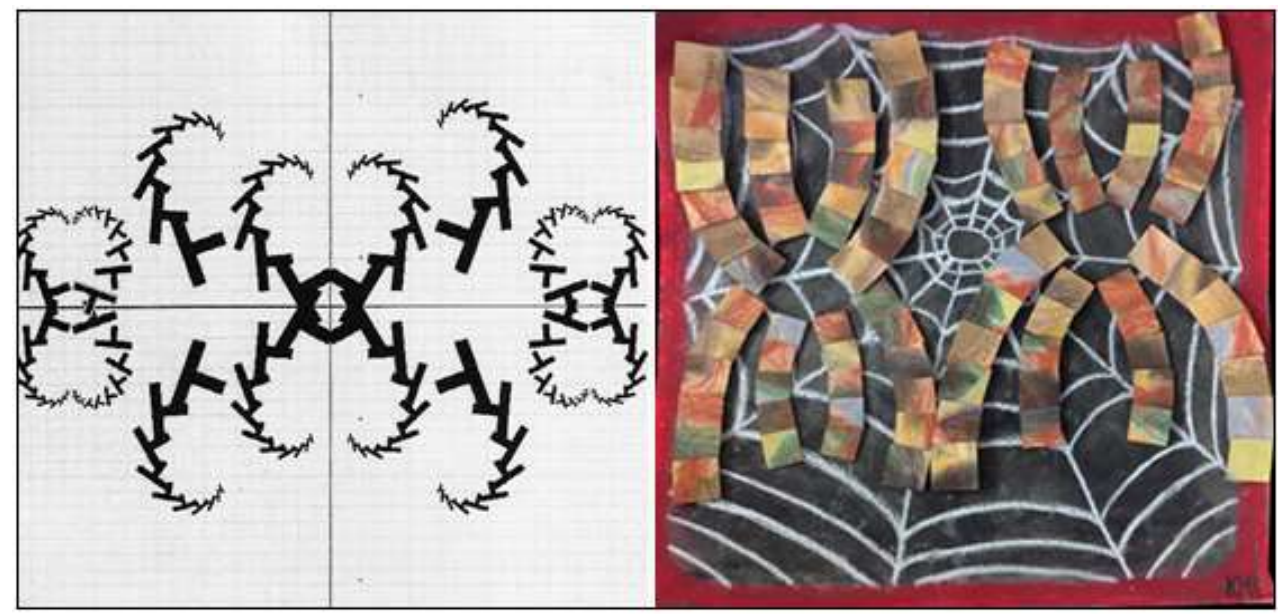

FIGURE 6 - Bennett's "ethnocomputational creativity" merges ethnomathematics, simulations and physical arts Source: By permission of Audrey Bennett

These were not rendered in a simple physical replication of the original patterns, but rather artistically reinterpreted, adding a second layer of agency and creativity to the process. She reports that students added narratives to these pieces describing issues such as
(C) ETD- Educação Temática Digital
Campinas, SP
v.19
n. 3
p. $761-785$
jul./set. 2017 
addiction, social dislocation or other themes indicating that at least some of the goals of empowering student self-expression and personal growth were achieved (BENNETT et al., 2016).

Another intersection between generative STEM and vernacular culture is sports. Few examples better capture the concept of alienated value than the classic mathematics word problem involving the parabolic arc of a ball in sports. Does anyone honestly think that a student who is completely disengaged from a mathematics class but loves sports will suddenly begin solving equations because of these artificial and arbitrary examples? A generative approach begins by looking at the original unalienated case. Jhally (1989) describes a "sports/media complex" similar to the "military-industrial complex" - in this case extracting the expressive value created by fans. St. John (2014) suggests that the recent rise of sandlot baseball games amateur adults playing without sponsorship or even much formal organization - is a case of resistance to such commodification.

With this sense of a distinction between an authentic love of playing and its extractive and alienated forms, Drazan, Cooke, and Eglash (2016) describe a collaboration between the CSDTs and a "DIY ergonomics" program (http://community.csdt.rpi.edu/cms/application-contexts/diy-sports-science-lab). The program began with a professional force plate from RPI's biomechanics lab. We found that high school basketball players were highly motivated to improve their jump, and pre/post tests indicated that using the force plate metrics was changing their view of STEM education as relevant to their personal goals. Because the force plates were expensive lab apparatuses, our team developed a low-cost DIY version of the plate (figure 7) in which students could learn some electronics and carpentry.

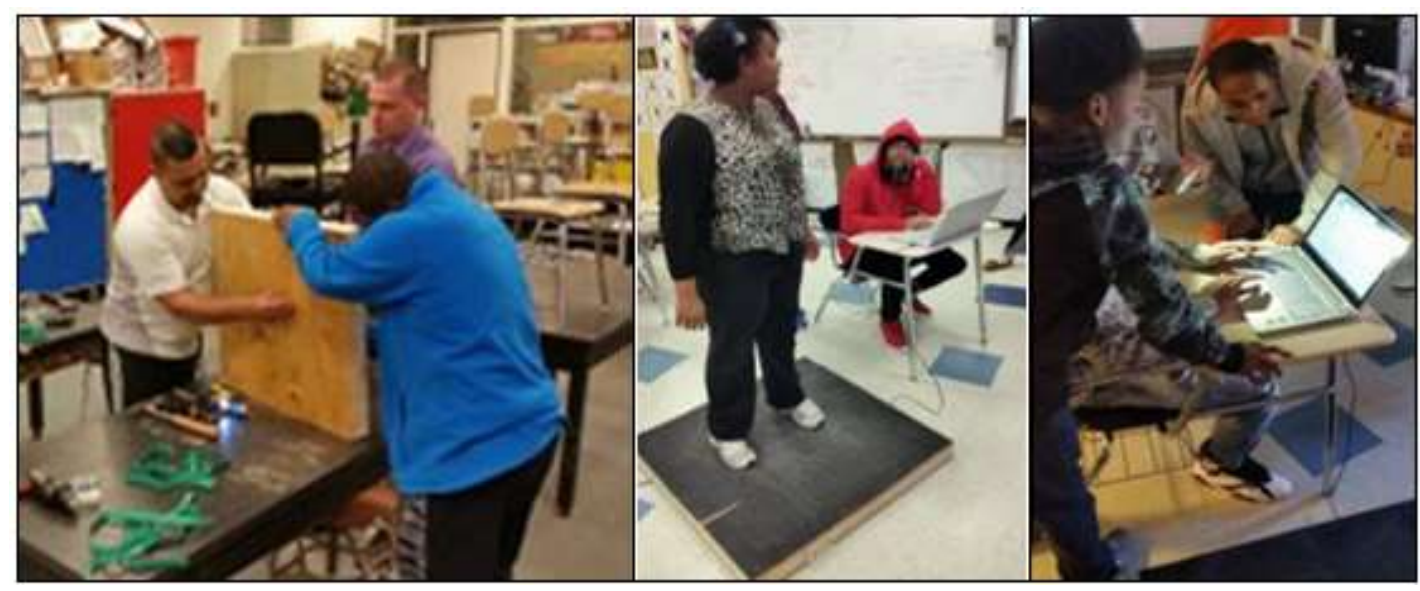

FIGURE 7 - Construction and testing of the DIY ergonomics lab force plate Source: By permission of the author
(C) ETD-Educação Temática Digital
Campinas, SP
v.19
n.3
p. $761-785$
jul./set. 2017

[775] 
Surprisingly, we found that building the plate turned out to be as popular as using it. As before, all code and blueprints are open source, so anyone can build and modify the original. The site linked above has now been expanded to incorporate a photogate to measure dribbling rates; a gravity simulation so that students can see how high they would jump on other planets, and a heat map application in which students can investigate their optimal location given the combination of likelihood of "makes" and the points for different spots.

While the material embodiment and ways in which this embeds STEM in the actual athletic context is critical to the prevention of alienation of value, John Drazan, the biomedical engineering student who originated the project, was able to further increase the generative flow (figure 8) by developing a peer-to-peer education system in which high school students would teach STEM sports to younger kids. This was carried out with our community partner, $4^{\text {th }}$ Family Inc. In contrast to the typical robotics competition that takes place at universities, symbolically sending the message that becoming a scientist means leaving the low-income community, the $4^{\text {th }}$ Family coaches, players and trainers kept the STEM workshops local, making them easily attended by the students' families.

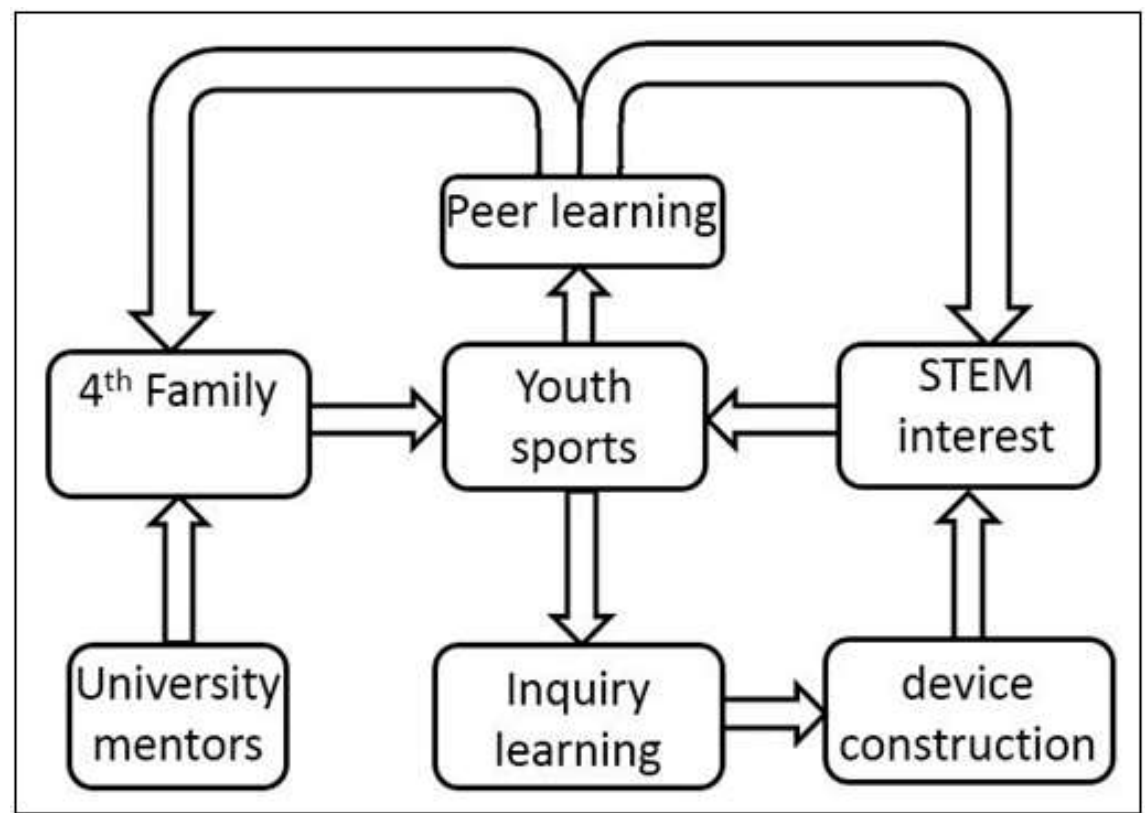

FIGURE 8 - Generative flow in the CSDT sports science program

Source: By permission of the author

In summary: a generative STEM approach for vernacular materials has a somewhat different set of challenges from those of indigenous origins. It requires careful identification of unalienated dimensions, because vernacular activities are typically embedded in a commodified landscape to begin with. On the other hand a reflexive participatory design process is equally important in the vernacular case; here too thoughtful reflection can (C) ETD-Educação Temática Digital Campinas, SP $\quad$ v.19 $\quad$ n.3 $\quad$ p.761-785 jul./set. 2017 
inspire a recursive knowledge exchange, and it can become the basis for non-proprietary, open source sharing, modeled on the indigenous commons. However that is not the end of the possibilities for generative STEM.

\section{NETWORKING GENERATIVE STEM IN THE COMMUNITY}

The third tool in our box is network topology. Recent work suggests that natural ecosystems maintain their stability by establishing flows of value (carbon cycles, food webs, and so on) through networks that exhibit power law distributions (MICHEL, 2009), allowing bottom-up self-organizing processes to create highly connected hubs.

If we truly want to move society towards systems that replace top down extraction with bottom up circulation, we need to reposition STEM as one of these highly connected hubs, linking science, social justice and sustainability as integrated parts of a technosocial ecosystem. Elsewhere, we have described this process in Ghana, where we created a network around simulations of Adinkra (stamped textile) designs that linked STEM education with the use of solar energy for Adinkra ink; HIV prevention through an Adinkrabased communication program; and local entrepreneurship (LACHNEY et al., 2016a).

Here we describe a similar cycle of value between school and community in the United States using cornrow hairstyles. The geometric and computational possibilities for cornrow hairstyles were first described in the book African Fractals (EGLASH, 1999), and they were the first simulation of the CSDT suite (EGLASH, BENNETT, O'DONNELL JENNINGS; CINTORINO, 2006). The current simulation (figure 9) uses a programming interface, and supports both mathematics and computing education. 


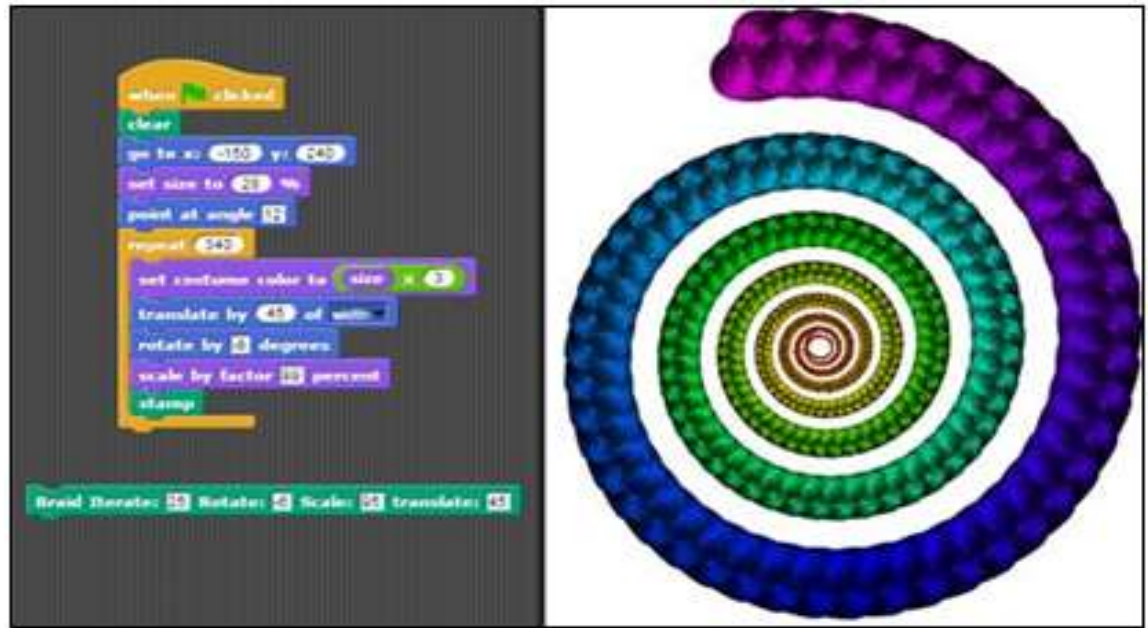

FIGURE 9 - The Cornrow Curves simulation interface Source: By permission of the authors

This website (https://community.csdt.rpi.edu/cms/application-contexts/cornrowcurves) includes rich background information on the cultural history of cornrow braiding, from its African origins, across the middle passage, to contemporary pop culture. Observing that African American students we surveyed thought that cornrows were a recent invention ("Brooklyn" was the most common answer for its origins) firmed our hypothesis that this cultural background is crucial to imparting the concept of "heritage algorithms", which directly contradict the myths of genetic and cultural determinism in mathematics (as noted previously). Qualitative and quantitative analysis of African American students using the Cornrow Curves CSDT shows that students not only improve their understanding and interest in computing in comparison to baseline populations, but that this changes their understanding of their own heritage as one that includes mathematics and computational thinking (EGLASH; BENNETT, 2009).

The next step are interactive tutorials; a key means of merging computational thinking with other STEM concepts. The image of one "plait" (twist of hair) is repeated many times, with each iteration applying geometric transforms (rotation, scaling, and translation) to create the scaling pattern of a braid. Thus the merger of computational thinking and mathematical thinking are vividly portrayed in the structure of the braid itself. The tutorials approach this gradually, allowing the student trial and error experimentation with each parameter (iteration number and transform values) to gain some level of mastery over the concept. The next step shows how implicit variables such as a color value can be included in the iteration. Finally a "custom block" is introduced which encapsulates the iterative loop script into a single braid block (lower left of figure 9). This teaches the concept of function, and allows students to easily create nested loops with a small script that generates an entire hair style.
(C) ETD-Educação Temática Digital
Campinas, SP
v.19
n.3
p. $761-785$
jul./set. 2017 
Figure 9 shows a student's work from a recent workshop in Upstate New York. Although the custom block for creating multiple braids was not used, the trial and error process tweaking parameters to maximize the number of revolutions showed strong engagement. This particular image was produced by an African American student the teacher described as typically disengaged. She noted that it was not only unusual for him to participate but that when other students saw what he had done they asked him for help in replicating the pattern, which was an rewarding classroom experience for him.

From the tutorial students can move to the full application, as well as teaching materials such as lesson plans, samples of student work, etc. A gallery of real-world hairstyles is available for students who want the challenge of replicating a goal image, but most prefer to create their own designs. Simply reinforcing the concepts learned in the tutorial is an important part of the learning at this stage, and pre/post tests are largely focused on these since that will be universal to all participants. However the students that are inspired to learn new blocks and concepts are often some of the most promising, so our evaluation includes script complexity metrics. Learning modules, which score high in this metric would imply that it inspires many students to make highly complex scripts; a crucial piece of information for teachers looking to maximize advances in computational thinking.

In order to complete the cycle between community and school we engaged Master Stylist and entrepreneur Nicole Daly, owner of Hair Journeys Salon LLC in Albany New York. Nicole first learned to use the software herself, and then developed a short introduction using mannequins from her shop. Figure 10 shows Nicole presenting to students in a mathematics classroom.

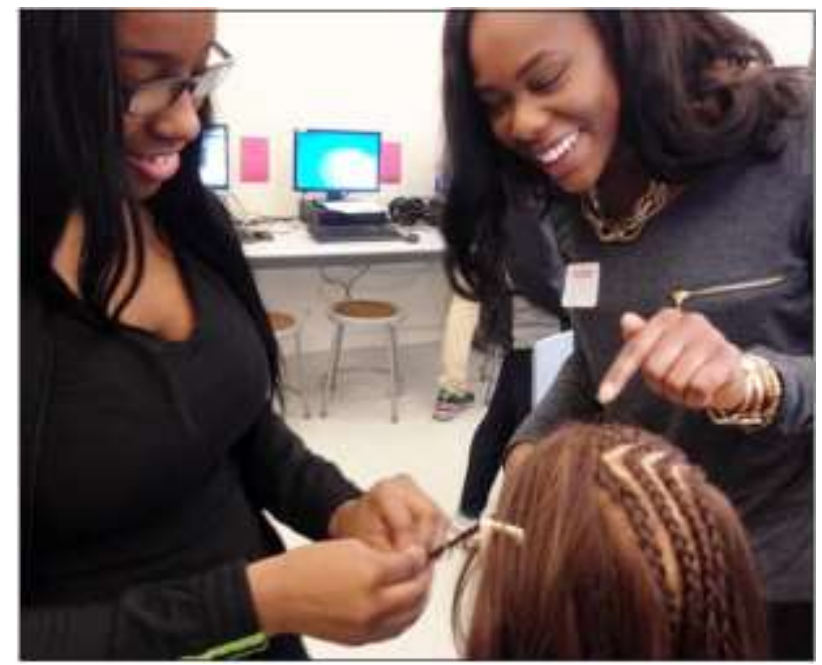

FIGURE 10 - Master stylist Nicole Daly demonstrates braiding in the classroom

Source: By permission of the authors

(C) ETD-Educação Temática Digital $\quad$ Campinas, SP $\quad$ v.19 $\quad$ n.3 $\quad$ p.761-785 jul./set. 2017


It is a common error to assume that the ethnosciences need only show the mathematics connection, and that all cultural knowledge is already in the student. To the contrary, it is the responsibility of researchers and teachers to offer a respectful and sophisticated presentation of the cultural materials, ensuring that the flow of value is validated as something worth classroom time and scholarly attention. Bringing a stylist into the classroom (similar to the ways that Lipka, Hogan, Webster, Yanez, Adams, Clark, and Lacy (2005) have done for Yupik Elders) increases the pathways for unalienated flow. Now that we have brought a stylist to the classroom, our next step will be to circulate value in the other direction. For example, figure 11 shows a 3D printer creating a mannequin head with one of the student-generated designs.

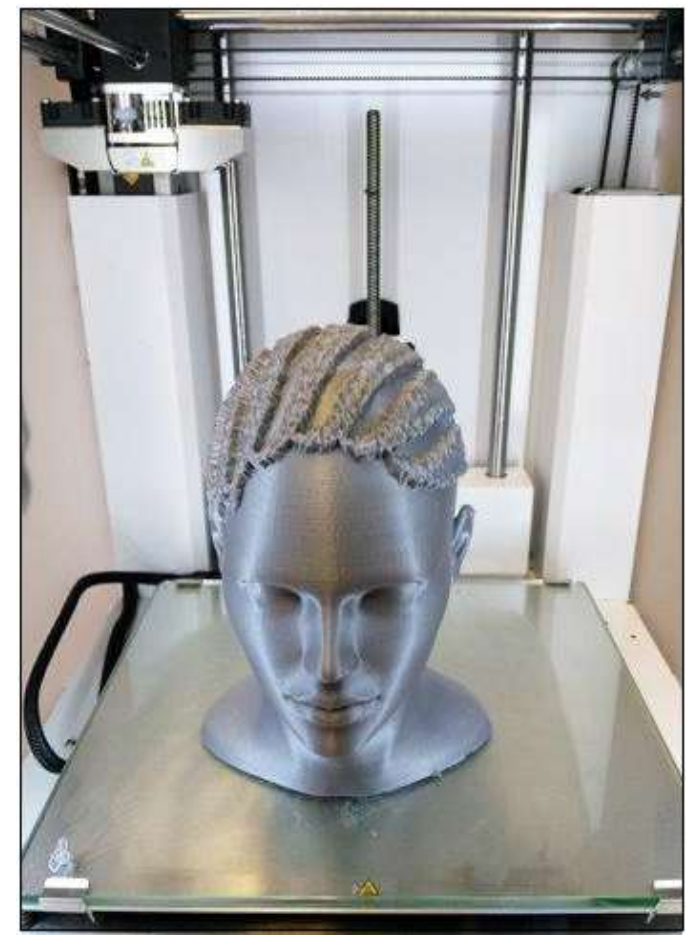

FIGURE 11 - 3D printer rendering a virtual cornrow design as a mannequin head Source: by permission of the author

Our next step will be running our workshop through a local vocational school in which students can get cosmetology certification. The teacher tells us that the certification is financially out of reach for many low-income students after high school graduation, but they are often unable to complete it during school because of science requirements that force them to drop the course. If we are successful in the formal incorporation of STEM in the cosmetology class, we may be able to alleviate that challenge. By the end of the workshop students will be installing their custom designed mannequins at local braiding shops. They will be designing their own analysis to gather data that can determine whether or not the shops with these mannequins receive an increase in the number of customers.
(C) ETD-Educação Temática Digital
Campinas, SP
v.19 n.3
p. $761-785$
jul./set. 2017 
One braider (Laquita Love, who is also the cosmetology instructor at the school) has already made suggestions for technology innovations that could be used by braiders to further their craft. By a participatory design process in the hands of low-income entrepreneurs we can design technologies in a partnership that diversifies who benefits from the products of STEM university research - the output of the STEM pipeline - rather than limiting diversity to the input of a pipeline which is ultimately benefitting large corporations and the military.

In the second section we noted the "typical claim to any kind of STEM diversity lies in the assumption that this will improve STEM learning outcomes, and thus benefit the children of the indigenous community. As we will see shortly, this is not always a reliable assumption". The reason that this is not always a reliable assumption is that the STEM military-industrial complex is one of the factors which produces underrepresentation, including pollution, health issues, poor services, etc. For example, the dramatic increase in wealth inequality (figure 12) has been greatly accelerated by computing, automation, robotics, and other fields in which the extraction of value from prior generations of humans and nonhumans (ecological value) have resulted in a means of production designed to exclude community claims to the value generated.

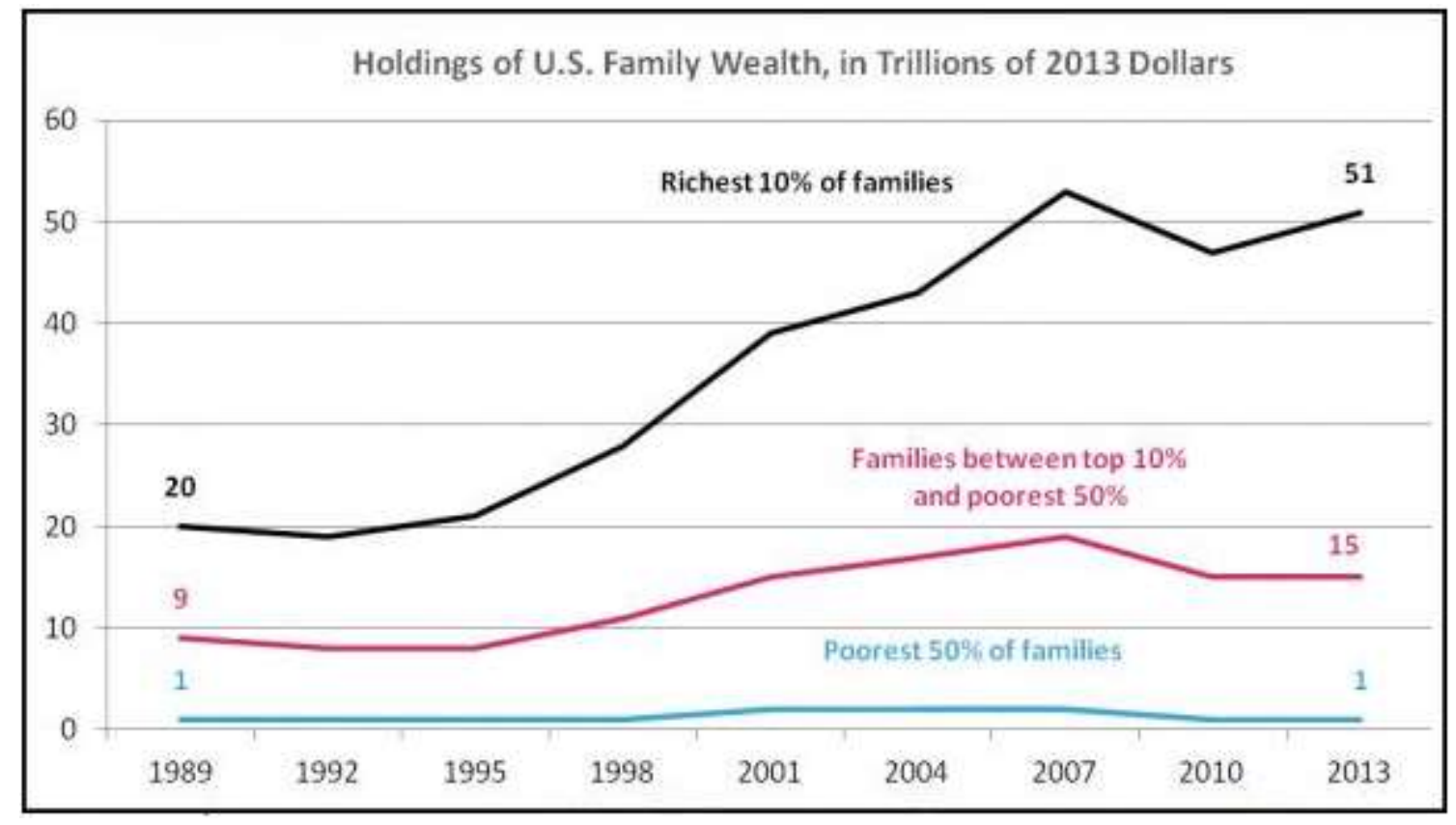

FIGURE 12 - Wealth inequality in the US

Source: Congressional Budget Office, Trends in Family Wealth, 1989-2013, August 2016
(C) ETD- Educação Temática Digital
Campinas, SP
v.19
n.3
p. $761-785$
jul./set. 2017 
Redesigning technology such that the productive infrastructure keeps value in unalienated form, and fosters its circulation rather than exclusion, can only be achieved if we use something like generative justice as our guide. By embedding technological innovations like 3D printing in a circuit of STEM education that includes low income entrepreneurs, university researchers, and ethnosciences we can replace extraction with circulation, and honor generations of tradition and creativity based on sustainable and just principles and practices.

\section{RESULTS}

As noted above, some of the most important aspects are qualitative: integrating STEM education with support for cultural traditions and heritage practices; with new opportunities for supporting artisanal labor through STEM innovation; with communitybased sustainability innovation, and so on. But quantitative testing is important too. In Eglash et al. (2011), we carried out a controlled in two high school computing classes in New York City. Students in the morning section of the class used a popular (non-cultural) site for fractals education, the afternoon section used our CSDTs for African Fractals, which had similar lessons using culture-based fractals.

The pre/post differences in mathematics and computing skills showed statistically significant improvement (.001 confidence level) in the class using the CSDT website, in comparison to the control group using similar software without any cultural references. Similar results were obtained using a pre/post test for attitudes toward computing careers. In Babbitt et al (2015), we ran the same research design in Kumasi, Ghana rather than New York City. Again, the intervention group obtained statistically significant improvement in comparison to the control group, which used similar software without any cultural references.

\section{CONCLUSION}

Rather than passively accept the concepts of social justice from humanities scholars, and then attempt to apply them to education, researchers in ethnomathematics, ethnocomputing and similar endeavors should be active social theorists as well. By utilizing complexity theory and self-organization models as a foundation for generative justice we can offer new insights into the possibilities for a more just and sustainable future.

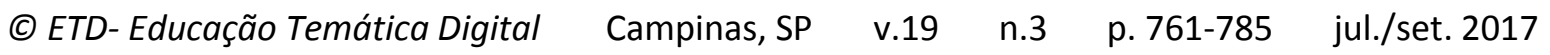




\section{REFERENCES}

BENKLER, Yochai. Practical anarchism: peer mutualism, market power, and the fallible state. Politics and Society, v. 4, n. 2, p. 213-251, 2013.

BENNETT, Audrey. Ethnocomputational creativity in STEAM education: a cultural framework for generative justice. Teknokultura. Journal of Digital Culture and Social Movements, $v$. 13, 2016. Retrieved from: http://revistas.ucm.es/index.php/TEKN/article/view/52843.

BENNETT, Audrey; EGLASH, Ron; LACHNEY, Michael; BABBITT, William. Design agency: diversifying computer science at the intersections of creativity and culture. In: RAISINGHANI, M. (Ed.). Revolutionizing Education through Web-Based Instruction. Hershey, PA: IGI Global, 2016. p. 35-56.

BENNETT, Audrey; CASSIM, Fatima; VAN DER MERWE, Marguerite; VAN ZIJL, Karen; RIBBENS, M. Designing South African children's health education as generative play. Proceedings of the International Association of Societies of Design Research, Queensland University of Technology, 2015.

BUECHLEY, Leah; HILL, Benjamin, M. LilyPad in the wild: how hardware's long tail is supporting new engineering and design communities. Proceedings of designing interactive systems. New York, NY: ACM, 2010. p. 199-207.

CLUIS, Corinne. Bioprospecting: a new western blockbuster, after the gold rush, the gene rush. The Science Creative Quarterly, v. 8, 2013. Retrieved from:

http://www.scq.ubc.ca/bioprospecting-a-new-western-blockbuster-after-the-gold-rush-thegene-rush/.

EGLASH, Ron; BANKS, David A. Recursive depth in generative spaces: democratization in three dimensions of technosocial self-organization. The Information Society, v. 30, n. 2, p. 106-115, 2014.

EGLASH, Ron, BENNETT, Audrey, O'DONNELL, Casey, JENNINGS, Sybillyn, CINTORINO, Margaret. Culturally situated designed tools: ethnocomputing from field site to classroom. American Anthropologist, v. 108, n. 2, p. 347-362, 2006.

EGLASH, Ron; GARVEY, Colin. Basins of attraction for generative justice. In BANERJEE, Santo, ERÇETIN, Şefika Şule, TEKIN, Ali (Eds.). Chaos Theory in Politics. Netherlands: Springer, 2014. pp. 75-88.

EGLASH, Ron. An introduction to generative justice. Teknokultura, v. 13, n. 2. Retrieved from:

(C) ETD-Educação Temática Digital $\quad$ Campinas, SP $\quad$ v.19 $\quad$ n.3 $\quad$ p.761-785 jul./set. 2017 
https://www.researchgate.net/publication/311811471_An_Introduction_to_Generative_Jus tice. 2016b.

DRAZAN, John F.; COOKE, Laquana; EGLASH, Ron. Harmonious integration: tuning STEM education with generative justice. IEEE Integrated STEM Education Conference. Princeton, NJ: ISEC, 2016. p. 58-64. Retrieved from:

https://www.researchgate.net/publication/301914824_Harmonious_integration_Tuning_ST EM_education_with_generative_justice.

DUNBAR-HESTER, Christina. Freedom from jobs or learning to love to labor? Diversity advocacy and working imaginaries in open technology projects. Teknokultura, v. 13, n. 2, p. 541-566, 2016.

JHALLY, Sut. Cultural studies and the sports/media complex. In WENNER, L. A. (Ed.). Media, sports, and society. Newbury Park, CA: Sage Publications, 1989. p. 70-96.

LACHNEY, Michael, BENNETT, Audrey, APPIAH, J.; EGLASH, Ron. Modeling in ethnocomputing: replacing bi-directional flows with recursive emergency. International Journal for Research in Mathematics Education, v. 6, n. 1, p. 219-243, 2016a.

LACHNEY, Michael; BABBITT, William; EGLASH, Ron. Content aware software design in the 'construction genre' of learning technology. Software Studies, v. 5, Special Issue, 2016b. Retrieved from http://computationalculture.net/article/software-design-in-theconstruction-genre-of-learning-technology-content-aware-versus-content-agnostic.

LACHNEY, Michael. Culturally responsive computing as brokerage: toward asset building with education-based social movements. Learning, Media and Technology, p. 1-20, 2016. DOI: 10.1080/17439884.2016.1211679.

LYLES, Dan.; LACHNEY, Michael; FOSTER, Ellen K.; ZATZ, Zoe. Generative contexts: generating value between community and educational settings. Teknokultura, v. 13, n. 3, p. 613-637, 2016.

LIPKA, Jerry; HOGAN, Maureen, P.; WEBSTER, Joan P.; YANEZ, Evelyn; ADAMS, Barbara; CLARK, Stacy; LACY, Doreen. Mathematics in a cultural context: two case studies of a successful culturally based mathematics project. Anthropology \& Education Quarterly, v. 36, n. 4, p. 367-385, 2005.

MARX, Karl. Capital. Volume I. New York, NY: Vintage, 1976.

MITCHEL, Melanie. Complexity: a guided tour. New York, NY: Oxford Univ., 2009.

(C) ETD- Educação Temática Digital $\quad$ Campinas, SP $\quad$ v.19 $\quad$ n.3 $\quad$ p.761-785 $\quad$ jul./set. 2017 
ROSA, Milton; OREY, Daniel Clark. Ethnomodeling as a research theoretical framework on ethnomathematics and mathematical modeling. Journal of Urban Mathematics Education, v. 6, n. 2, p. 62-80, 2013.

ST. JOHN, Warren. Sandlot baseball: diamonds in the rough. Garden \& Gun, 2014. Retrieved from: http://gardenandgun.com/article/sandlot-baseball-diamonds-rough.

\section{Acknowledgement}

The authors would like to acknowledge NSF grants DRL-1640014 and DGE-0947980 in support of this work.

'The grammatical and editorial revisions of this article were made by Milton Rosa and Daniel Clark Orey (UFOP). 